Quebec Cooperative Study

of Friedreich's Ataxia

\title{
Glycosylated Hemoglobins In Friedreich's Ataxia
}

\author{
P. DRAPER, D. SHAPCOTT, M. LANGLOIS, B. LEMIEUX
}

SUMMARY: In a study of glycosylated hemoglobins in Friedreich's Ataxia patients and in family members, the level was found to be higher in insulin dependent diabetics than in healthy non-diabetic control subjects $(p<0.01)$, but was similar to non-ataxic diabetic control subjects. Results for non-diabetic Friedreich's Ataxia patients and siblings were similar to

RESUME: Lors d'une étude de l'hémoglobine glycosylée chez des patients avec ataxie de Friedreich et chez des membres de leur famille, des taux plus élevés $(p<0.01)$ furent trouvés chez les diabétiques insulino-dépendants que chez les sujets contrôlés sains non diabétiques, mais ces taux étaient semblables à ceux des sujets contrôlés diabétiques non ataxiques. Les résultats chez les patients ataxiques non diabétiques et leur fratrie furent those for non-diabetic control subjects while levels were slightly increased in the heterozygotes. It is concluded that in Friedreich's Ataxia patients and family members (apart from the insulin dependent diabetics), there was no hyperglycemia sufficient to be detected as an increase in glycosylated hemoglobins.

semblables à ceux des sujets contrôles non diabétiques, tout en étant légèrement élevés chez les hétérozygotes. Nous concluons que chez les patients avec ataxie de Friedreich et les membres de leurs familles (sauf ceux qui sont diabétiques insulinodépendants), il n'y a pas d'hyperglycémie suffisante pour être décelée par une augmentation des hémoglobines glycosylées.

\section{INTRODUCTION}

The increased incidence of clinical and chemical diabetes in Friedreich's Ataxia has been described in this (Shapcott et al., 1976, Draper et al., 1979) and other laboratories. While a number of patients are insulin dependent diabetics, there is also a significant fraction of borderline cases, where a mild glucose intolerance or chemical diabetes is present. A hyperinsulinemic response to the oral glucose tolerance test (OGTT) is also noted in many Friedreich's ataxia patients. It was suggested that the observed glucose intolerance, especially in the borderline cases, could be due in part to the low muscle mass, and hence, abnormal glucose utilization.

With the recent development of more rapid chromatographic assays for glycosylated or "fast" hemoglobins, this approach is gaining acceptance as an additional method for assessing the degree of control of hyperglycemia in diabetic patients. We have therefore measured glycosylated hemoglobin levels in Friedreich's Ataxia patients and in family members to determine the extent of sustained hyperglycemia in these subjects, and thus further defining the diabetic status in Friedreich's Ataxia.

\section{SUBJECTS AND METHODS}

Typical Friedreich's ataxia (Group 1 a) patients (Shapcott et al., 1976) and family members (heterozygotes and siblings*) were studied. Non-diabetic control subjects were apparently healthy adult volunteers from laboratory and secretarial personnel, while diabetic controls were poorly controlled adult diabetics being monitored in the Diabetes Clinic, CHUS.

Blood samples for glycosylated hemoglobin determinations were collected in tubes containing EDTA, 
while samples for plasma glucose were collected in tubes containing oxalate. Plasma glucose was determined by the o-tuluidine method. Glycosylated hemoglobins were determined by two methods: 1) Total fast hemoglobin $\left(\mathrm{HbA}_{\mathrm{a} a} t_{\mathrm{b}} t_{\mathrm{c}}\right)$ was estimated using the Helena Glycosylated Hemoglobin Quik Column Kit (Helena Laboratories, Beaumont, Texas). 2) Hemoglobins $\mathrm{HbA}_{1 \mathrm{a}} t_{b}$ and $\mathrm{HbA}_{1 \mathrm{c}}$ were determined using the micro chromatographic method of Jones et al. (1978). The results of these determinations are expressed as the percentage of the total hemoglobin.

*Siblings: possible heterozygotes and normal

\section{RESULTS}

Table I shows the mean percentage of glycosylated hemoglobins in the various groups, as determined by the two methods, along with the plasma glucose. The distribution of the total fast hemoglobins (method 1) for each of the subject groups is illustrated graphically in Fig. 1.

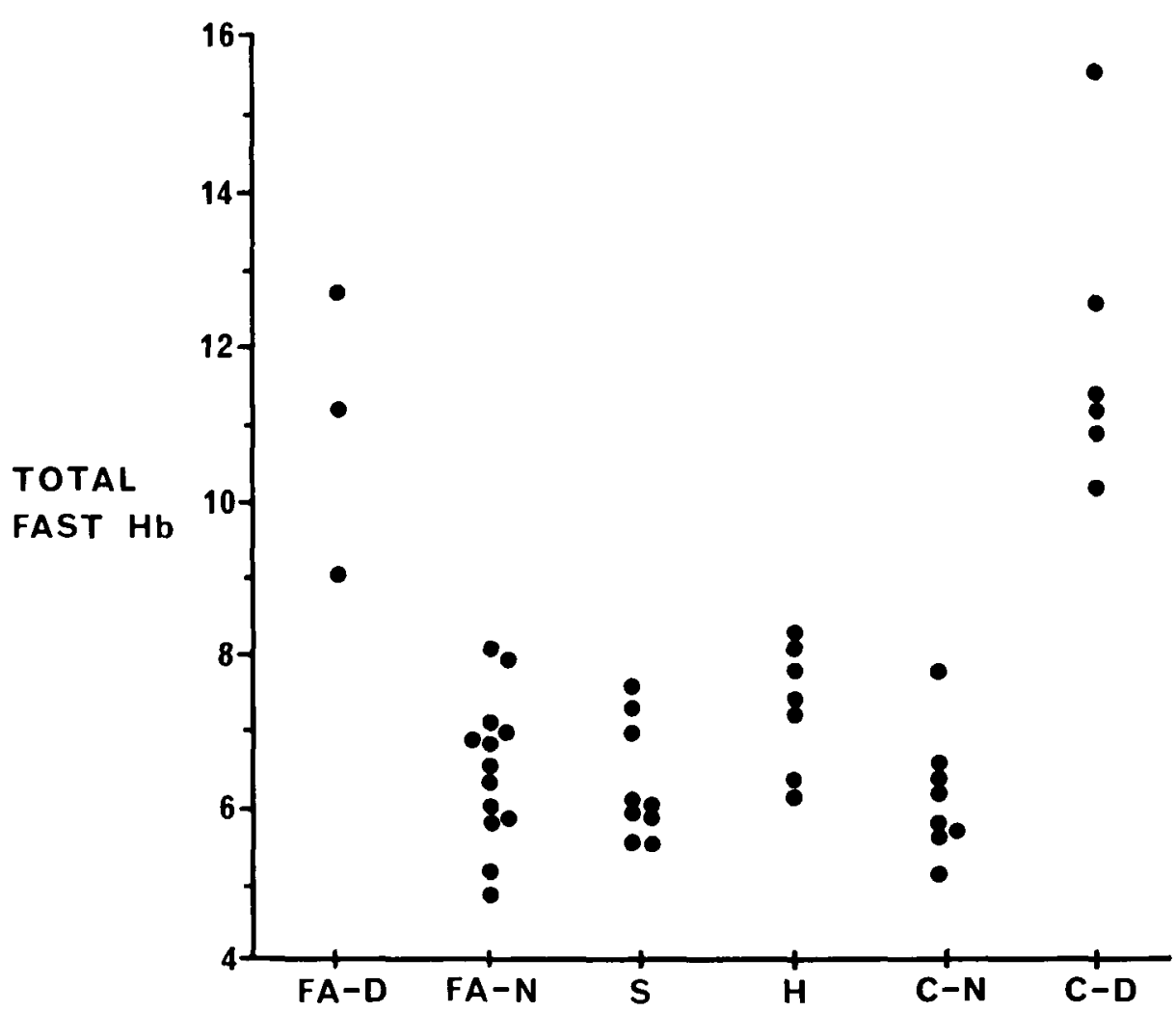

Figure I - Distribution of total fast hemoglobin (method I). Abbreviations are: FA-D, Friedreich's Ataxia - diabetic; FA-N, Friedreich's Ataxia - non-diabetic; S, Siblings; H, Heterozygotes; C-N, Controls - non-diabetic; C-D, Controls - diabetic. ambiguity in interpretation of these results, an alternative method for detection of a sustained hyperglycemia in these patients is desirable. Determination of glycosylated or "fast" hemoglobins represents an attractive approach especially with the recent introduction of rapid chromatographic assays.

At least four fast hemoglobins are known (Dods and Bolmey, 1979): of these $\mathrm{HbA}_{\mathrm{lc}}$ is the major component and has been the most widely studied. $\mathrm{HbA}_{\mathfrak{~}}$ has been shown to be formed by a slow, essentially irreversible reaction of the major hemoglobin $\mathrm{HbA}_{\mathrm{II}}$ with glucose throughout the lifetime of the red cell (Gonen and Rubenstein, 1978). Thus, the $\mathrm{HbA}_{1 \mathrm{c}}$ level represents a time averaged glucose concentration over the life of the red cell, and as a consequence, levels in poorly controlled diabetics are approximately twice the normal values. Furthermore, levels decrease to near normal over a period of several weeks after initiation of control of hyperglycemia. Although there is now some controversy over the effects of short-term variations in blood glucose on glycosylated hemoglobin levels (Brooks et al., 1979, Leslie et al., 1979) this method has gained acceptance as an approach to the evaluation of the degree of control of hyperglycemia without the wide variation possible from single glucose determinations.

The $\mathrm{HbA}_{1 \mathrm{c}}$ fraction is increased the most in poorly controlled diabetic patients, therefore we determined $\mathrm{HbA}_{\mathrm{lc}}$ levels as well as the total glycosylated hemoglobins, since there existed the possibility that changes in $\mathrm{HbA}_{1 c}$ could be masked in the total fast hemoglobin determination. However, the minor glycosylated hemoglobins also increase in diabetes, and we found that the much faster and easier total glycosylated hemoglobin determination using the commercially available kits gave results which parallel those for $\mathrm{HbA}_{1 \mathrm{c}}$ (Table 1).

The greatly increased glycosylated hemoglobins in the insulin dependent diabetic Friedreich's Ataxia patients are consistent with the increased blood glucose in these subjects (Table 1). Williams and Savage (1979) have suggested that the glycosylated hemoglobin approach constitutes a more 
TABLE I

Glycosylated Hemoglobins in Friedreich's Ataxia

(Mean \pm S.D., as percent of total hemoglobin).

\begin{tabular}{lccccccc} 
& $\begin{array}{c}\text { Plasma glucose } \\
(\mathbf{m g} / \mathbf{1 0 0 m l})\end{array}$ & $\mathbf{N}$ & $\begin{array}{c}\text { Method 1 } \\
\text { Total Fast Hb }\end{array}$ & $\mathbf{N}$ & $\mathbf{H b A}_{\mathbf{l a}+\mathrm{b}}$ & $\mathbf{H b A}_{1 \mathrm{c}}$ \\
& $202 \pm 35^{\mathrm{d}}$ & 3 & $10.93 \pm 1.86^{\mathrm{C}}$ & 3 & $2.80 \pm 0.03$ & $10.27 \pm 0.50^{\mathrm{d}}$ & 3 \\
$\begin{array}{l}\text { Friedreich's Ataxia, } \\
\text { diabetic }\end{array}$ & $89 \pm 11$ & 15 & $6.50 \pm 0.96$ & 13 & $2.15 \pm 0.29$ & $4.89 \pm 0.55$ & 14 \\
$\begin{array}{l}\text { Friedreich's Ataxia } \\
\text { non-diabetic }\end{array}$ & $108 \pm 46$ & 18 & $7.33 \pm 2.10^{\mathrm{a}}$ & 16 & $2.26 \pm 0.37$ & $5.84 \pm 2.18$ & 17 \\
$\begin{array}{l}\text { Friedreich's Ataxia, } \\
\text { combined }\end{array}$ & $89 \pm 8$ & 9 & $6.30 \pm 0.77$ & 9 & $2.08 \pm 0.41$ & $5.01 \pm 0.72$ & 6 \\
$\begin{array}{l}\text { Siblings } \\
\text { Heterozygotes }\end{array}$ & $101 \pm 21$ & 9 & $7.27 \pm 0.82^{\mathrm{b}}$ & 7 & $2.64 \pm 0.67$ & $5.38 \pm 1.14$ & 6 \\
$\begin{array}{l}\text { Controls, non-diabetic } \\
\text { Controls, diabetic }\end{array}$ & $92 \pm 12$ & 11 & $6.08 \pm 0.81$ & 8 & $2.19 \pm 0.50$ & $5.13 \pm 0.71$ & 11 \\
\hline
\end{tabular}

a $p \approx 0.05$ compared with non-diabetic control group

b $\mathrm{p}<0.02$ compared with non-diabetic control group

c $\mathrm{p}<0.01$ compared with non-diabetic control group

d $\mathrm{p}<0.001$ compared with non-diabetic control group

objective monitor of blood glucose control in children with diabetes mellitus than other commonly used methods, and therefore measurement of fast hemoglobin levels could be recommended in assessing the long term control of diabetes in Friedreich's Ataxia patients.

The non-diabetic Friedreich's Ataxia patients do not show a significant increase in fast hemoglobin, in spite of the abnormal GTT and the abnormal insulin response to the GTT shown by a number of these patients. We therefore conclude that any sustained hyperglycemia in this group is not sufficient to significantly raise the fast hemoglobin levels. These results are in agreement with those of a recent study (Dods and Bolmey, 1979) in which it was concluded that fast hemoglobin measurements are consistent with a conservative approach to the diagnosis of diabetes. The results are also consistent with the idea that the observed glucose intolerance in a number of these subjects may be due to their inability to utilize a glucose load at a normal rate (due to their low muscle mass), but they do not exhibit a sustained hyperglycemia.

No increase in glycosylated hemoglobins was found for the siblings, while the slight increase in the total fast $\mathrm{Hb}$ in the heterozygotes (as deter- mined by Method 1) parallels a slight (but not significant) increase in blood glucose levels which may in part represent a natural trend with increasing age. The increase in $\mathrm{HbA}_{\mathrm{Ic}}$ for this group was not significant. As mentioned previously, the apparent difference between the two methods may be partly explained by the fact that only 4 subjects were subjected to both analytical methods.

In summary, we have measured glycosylated hemoglobins in Friedreich's Ataxia patients and in family members to determine whether the measurement of fast hemoglobins provides a more sensitive index of glucose intolerance than plasma glucose determinations. It is concluded that in Friedreich's ataxia patients and family members (apart from the insulin dependent diabetics), there was no hyperglycemia sufficient to be detected as an increase in glycosylated hemoglobins. This approach can be recommended as part of the protocol in the long term monitoring of the control of diabetes in Friedreich's ataxia.

\section{ACKNOWLEDGEMENTS}

The studies reported in this paper were supported in part by a grant from l'Association Canadienne de l'Ataxie de Friedreich. We also wish to acknowledge the technical assistance of Mrs. Gisele Carrier.

\section{REFERENCES}

BROOKS, A.P., BAIRD, J., and NAIRN, I.M. (1979). Rate of change of hemoglobin $A_{1}$ in diabetic patients. British Med. J., 2, 275.

DODS, R.F., and BOLMEY, C. (1979). Glycosylated hemoglobin assay and oral glucose tolerance test compared for detection of diabetes mellitus. Clin. Chem., 25, 764-768.

DRAPER, P., SHAPCOTT, D., LAROSE, A. STANKOVA, J., LEVESQUE, F. and LEMIEUX, B. (1979). Glucose tolerance and erythrocyte insulin receptors in Friedreich's Ataxia. Can. J. Neurol. Sci., 6, 233239.

GONEN, G., and RUBENSTEIN, A.H. (1978). Haemoglobin $\mathrm{Al}$ and diabetes mellitus. Diabetologia, 15, 1-8.

JONES, M.B., KOLER, R.D. and JONES, R.T. (1978). Microcolumn method for the determination of hemoglobin minor fractions $A_{1 a+b}$ and $A_{1 c}$. Hemoglobin, 2, 53-58.

LESLIE, R.D.G., PYKE, D.A., JOHN, P.N. and WHITE, J.M. (1979). How quickly can hemoglobin A, increase? British Med. J., 2 , 19.

SHAPCOTT, D., MELANCON, S., BUTTERWORTH, R.F., KHOURY, K., COLLU. R., BRETON, G., GEOFFROY, G., LEMIEUX, B., and BARBEAU, A. (1976). Glucose and insulin metabolism in Friedreich's Ataxia. Can. J. Neurol. Sci., 3, 361364.

WILLIAMS, M.L., and SAVAGE, D.C.L. (1979). Glycosylated haemoglobin in children with diabetes mellitus. Arch. Dis. Child., 54, 295-298. 